\title{
Effects of Insulin on Peripheral and Splanchnic Glucose Metabolism In Noninsulin-dependent (Type II) Diabetes Mellitus
}

\author{
Ralph A. Defronzo, Rolf Gunnarsson, Ola Björkman, Maggie Olsson, and John Wahren \\ Endocrine/Metabolism Division, Department of Internal Medicine, Yale University, School of Medicine, New Haven, Connecticut \\ 06510; and Departments of Medicine and Clinical Physiology, Karolinska Institute, Huddinge Hospital, Stockholm, Sweden
}

\begin{abstract}
The mechanism(s) and site(s) of the insulin resistance were examined in nine normal-weight noninsulin-dependent diabetic (NIDD) subjects. The euglycemic insulin clamp technique (insulin concentration $\sim 100 \mu \mathrm{U} / \mathrm{ml}$ ) was employed in combination with hepatic and femoral venous catheterization and measurement of endogenous glucose production using infusion of tritiated glucose. Total body glucose metabolism in the NIDD subjects $(4.37 \pm 0.45 \mathrm{mg} / \mathrm{kg}$ per $\mathrm{min})$ was $38 \%(P$ $<0.01)$ lower than in controls $(7.04 \pm 0.63 \mathrm{mg} / \mathrm{kg}$ per $\mathrm{min})$. Quantitatively, the most important site of the insulin resistance was found to be in peripheral tissues. Leg glucose uptake in the diabetic group was reduced by $45 \%$ as compared with that in controls $(6.0 \pm 0.2$ vs. $11.0 \pm 0.1 \mathrm{mg} / \mathrm{kg}$ leg wt per min; $P$ $<0.01$ ). A strong positive correlation was observed between leg and total body glucose uptake $(r=0.70, P<0.001)$. Assuming that muscle is the primary leg tissue responsible for glucose uptake, it could be estimated that 90 and $87 \%$ of the infused glucose was disposed of by peripheral tissues in the control and NIDD subjects, respectively. Net splanchnic glucose balance during insulin stimulation was slightly more positive in the control than in the diabetic subjects $(0.31 \pm 0.10 \mathrm{vs}$. $0.05 \pm 0.19 \mathrm{mg} / \mathrm{kg}$ per $\mathrm{min} ; P<0.07)$. The difference $(0.26$ $\mathrm{mg} / \mathrm{kg}$ per $\mathrm{min}$ ) in net splanchnic glucose balance in NIDD represented only $10 \%$ of the reduction $(2.67 \mathrm{mg} / \mathrm{kg}$ per min) in total body glucose uptake in the NIDD group and thus contributed very little to the insulin resistance. The results emphasize the importance of the peripheral tissues in the disposal of infused glucose and indicate that muscle is the most important site of the insulin resistance in NIDD.
\end{abstract}

\section{Introduction}

Noninsulin-dependent (type II) diabetes mellitus is well established as a heterogenous disorder characterized by defects in both insulin secretion and tissue sensitivity to insulin (1). The insulin resistance has been documented using various techniques that include the combined oral glucose/insulin tolerance test $(2)$, the insulin tolerance test $(3,4)$, the quadruple infusion technique $(5,6)$, radioisotope turnover studies (7), and the insulin clamp technique (8-12). The site of the insulin resistance, however, has not been clearly defined. In a general sense, insulin resistance could result from one of three major metabolic disturbances: impaired glucose uptake by peripheral

Received for publication 16 March 1984 and in revised form 11 March 1985.

J. Clin. Invest.

(c) The American Society for Clinical Investigation, Inc. 0021-9738/85/07/0149/07 \$1.00

Volume 76, July 1985, 149-155 tissues, impaired glucose uptake by the splanchnic tissues, or impaired suppression of hepatic glucose production (HGP). ${ }^{1}$ Of these three disturbances, only the latter has been examined in any detail. DeFronzo et al. $(8,9)$ found that basal HGP was slightly, although significantly, elevated in noninsulindependent diabetics (NIDD) with moderate fasting hyperglycemia $(140-200 \mathrm{mg} / \mathrm{dl})$. In NIDD with more severe fasting hyperglýcemia ( $>200-220 \mathrm{mg} / \mathrm{dl}$ ), the basal rate of HGP was increased in proportion to the increase in fasting plasma glucose concentration. In all diabetics, however, HGP was suppressed by $>90 \%$ by hyperinsulinemia (insulin clamp, plasma insulin concentration $\sim 100 \mu \mathrm{U} / \mathrm{ml}$ ). A similar elevation in basal HGP in NIDD was reported by Kolterman et al. (10, 11). These investigators, however, found that the ability of hyperinsulinemia to suppress HGP was impaired in NIDD. At present, no data are available concerning direct measurements of insulin-mediated glucose uptake by splanchnic and peripheral tissues.

To characterize completely the potential mechanisms responsible for the impairment in insulin action in type II diabetes mellitus, one must in the same individual quantitate total body glucose uptake, peripheral tissue glucose uptake, splanchnic glucose uptake, and suppression of HGP. In the present study we have attempted to provide an integrated picture of insulin-mediated glucose metabolism by employing the euglycemic insulin clamp technique in combination with measurements of endogenous glucose production (using tritiated glucose infusion) and the femoral/hepatic venous catheterization technique. As discussed above, it is well established that the defect in total body glucose uptake, as well as the ability of insulin to suppress hepatic glucose production, becomes progressively more impaired with increasing severity of diabetes (9). Since we were interested in examining the defect in glucose utilization at a relatively early stage in the evolution of diabetes mellitus, we chose to study patients with modest fasting hyperglycemia.

\section{Methods}

Subjects. The subject population consisted of 9 NIDD and 10 healthy control subjects. The diabetic group was composed of seven males and two females, the control group of nine males and one female. All subjects were within $20 \%$ of ideal body weight, based upon the mean point of medium frame individuals in the 1959 Metropolitan Life Insurance table. The mean $\pm S E M$ ideal body weight in the diabetic and control subjects averaged $95 \pm 4$ and $107 \pm 3 \%$, respectively. The actual body weights in the two groups were $71 \pm 5$ and $74 \pm 3 \mathrm{~kg}$, respectively. The diabetics were slightly older than the controls, $52 \pm 2$

1. Abbreviations used in this paper: HGP, hepatic glucose production; NIDD, noninsulin-dependent diabetes (diabetics); OGTT, oral glucose tolerance test; SER, splanchnic extraction ratio; SGB, splanchnic glucose balance; SGU, splanchnic glucose uptake. 
vs. $43 \pm 3 \mathrm{yr}$. The duration of diabetes, as established by the first recorded plasma glucose concentration $>140 \mathrm{mg} / \mathrm{dl}$, was $2.8 \pm 1 \mathrm{yr}$. Eight of the nine diabetic subjects fulfilled the criteria for diagnosis of diabetes mellitus as established by the National Diabetes Data Group (13). None of the diabetics had ever taken insulin or oral hypoglycemic agents before the study. Other than diabetes mellitus, no subject had any significant medical history and none was taking any medications. There was no family history of diabetes in the controls. Six of the nine diabetics had a positive family history of diabetes among first-degree relatives.

Each of the nine diabetic subjects received an oral glucose tolerance test (OGTT) $(1 \mathrm{~g} / \mathrm{kg}$ body wt) to evaluate their degree of glucose intolerance and their plasma insulin response. The fasting plasma glucose concentration on the day of the OGTT was $149 \pm 8 \mathrm{mg} / \mathrm{dl}$ (Fig. 1). The fasting plasma insulin concentration in the diabetics was $25 \pm 2$ $\mu \mathrm{U} / \mathrm{ml}$, and this was significantly greater than in the controls, $8 \pm 1$ $\mu \mathrm{U} / \mathrm{ml}(P<0.001)$. During the OGTT the mean plasma glucose concentration and insulin levels in the diabetics were significantly greater than in the controls (Fig. 1).

All studies were carried out at 8 a.m. after a 10-12 h overnight fast. The purpose, nature, and potential risks of the study were explained to all subjects and they gave informed consent before participating. The protocol was reviewed and approved by the Human Investigation Committee of the Yale University School of Medicine, and the Ethical Committee of the Huddinge Hospital.

Experimental protocol. Teflon catheters were inserted into an antecubital vein for the infusion of all test substances and into a femoral artery for blood sampling. The femoral artery catheter was also used to infuse indocyanine green dye for the determination of leg blood flow (14). A catheter was also inserted via the right femoral vein into a right-sided hepatic vein as previously described to quantitate net splanchnic glucose exchange (15). A fourth catheter was inserted into the left femoral vein to determine the recirculation of indocyanine green dye for the calculation of blood flow (14).

HGP was quantitated by the infusion of $\left[{ }^{3} \mathrm{H}\right] 3$-glucose (specific activity $11.5 \mathrm{Ci} / \mathrm{mmol}, 100 \%$ pure; New England Nuclear, Boston, MA). In the control group the labeled glucose was administered as a primed $(25 \mu \mathrm{Ci})$-continuous $(0.25 \mu \mathrm{Ci} / \mathrm{min})$ infusion. In the diabetic individuals the prime was increased in proportion to the increase in fasting plasma glucose concentration. The tritiated glucose infusion was started $2 \mathrm{~h}$ before the beginning of the insulin clamp study in the controls and $3 \mathrm{~h}$ before in the diabetics. Arterial plasma samples for determination of tritiated glucose specific activity were taken at 15min intervals for the first $90 \mathrm{~min}$ in the controls and for the first 150

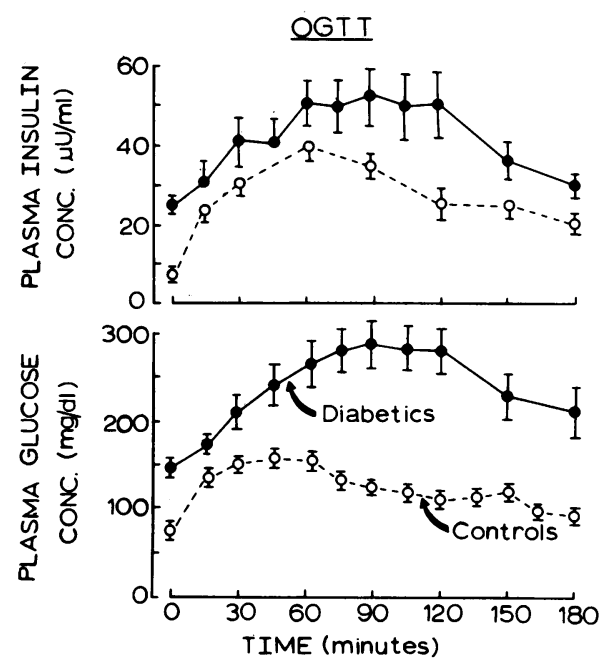

Figure 1. Plasma glucose and insulin concentrations (Conc.) after glucose ingestion in NIDD and control groups. min in the diabetics. During the last 30 min samples were taken at $5-$ 10-min intervals in both groups. A steady state plateau of tritiated glucose specific activity was achieved in all subjects during the last $\mathbf{3 0}$ min of the tracer infusion, and this plateau value was used to calculate basal HGP.

After $120 \mathrm{~min}$ (or $180 \mathrm{~min}$ in diabetics) of tritiated glucose infusion, a euglycemic insulin clamp study was performed (16). The plasma insulin concentration was acutely raised and maintained by a primecontinuous $\left(40 \mathrm{mU} / \mathrm{m}^{2}\right.$ per $\left.\mathrm{min}\right)$ infusion of insulin. This insulin infusion rate was chosen because it produces portal insulin levels (17) similar to those observed during a standard OGTT while achieving peripheral plasma insulin concentrations within the physiologic range. In the controls the plasma glucose concentration was maintained at the basal level by measurement of the arterial plasma glucose concentration at 5-min intervals and appropriate adjustment of the infusion of a $20 \%$ glucose solution based upon a negative feedback principle (16). In the diabetic subjects no glucose was infused after the insulin clamp was begun. Instead the plasma glucose concentration was allowed to decline to $90 \mathrm{mg} / \mathrm{dl}$, at which level it was clamped for $2 \mathrm{~h}$ more. During the insulin/glucose infusion, plasma samples for tritiated glucose specific activity were drawn every $15 \mathrm{~min}$ until the last $30 \mathrm{~min}$ of the insulin clamp, when they were drawn every 5-10 min.

Blood for the determination of hepatic and leg blood flow and of regional arteriovenous blood glucose concentration differences was drawn at $5-10$-min intervals over the $30 \mathrm{~min}$ before the insulin clamp was initiated and at 10-20-min intervals thereafter. After at least two or three basal determinations, plasma insulin (every $15 \mathrm{~min}$ ) and plasma glucagon, cortisol, growth hormone, epinephrine, and norepinephrine (every $30 \mathrm{~min}$ ) were measured periodically during the insulin clamp study. Hepatic blood flow was estimated by the continuous infusion technique using indocyanine green dye (15). Leg blood flow was determined by the dye dilution procedure described by Jorfeldt and Wahren (14), and leg weight was estimated by volume displacement. In brief, the subject's leg is inserted into a large water-filled cylindrical tank until the top of the cylinder meets the under surface of the bony attachment of the arcuate pubic ligament. The volume of water displaced from the tank is then measured. This procedure is repeated three times and mean value is calculated. When the leg volume of the same subject is determined by the same observer on three successive days, the variation is $<5 \%$.

Plasma glucose concentration was determined with a glucoseoxidase method (Glucostat; Beckman Instruments, Inc., Fullerton, CA). Whole blood glucose was determined by previously published methods (18). Plasma immunoreactive insulin was measured using talc to separate bound from free hormone (19), and plasma immunoreactive glucagon was determined using the $30 \mathrm{~K}$ antibody of Unger (20). Plasma catecholamine levels were measured using the radioenzymatic assay of Cryer (21). The method for plasma cortisol determination has been published previously (22). Counterregulatory hormones were determined only in the NIDD group.

Calculations. The amount of glucose metabolized by the entire body was calculated by adding the average glucose infusion rate and the rate of residual HGP. All data for total body, splanchnic glucose uptake (SGU) and hepatic glucose uptake, and HGP represent the mean of values during the last $100 \mathrm{~min}$ of the insulin clamp study. Steady state plasma insulin and glucose values were calculated for the same interval.

In the basal state, HGP was determined by dividing the $\left[{ }^{3} \mathrm{H}\right]$ glucose infusion rate (counts per minute per minute) by the steady state level of $\left[{ }^{3} \mathrm{H}\right]$ glucose specific activity achieved during the last $30 \mathrm{~min}$ of the tracer equilibration period. After insulin/glucose administration, a nonsteady condition in glucose specific activity exists, and HGP was calculated using a two-compartmental model previously described (23). The rate of HGP was calculated by subtracting the glucose infusion rate from the rate of glucose appearance as determined by the tracer technique.

Net splanchnic glucose balance (SGB) was calculated as the product of the arterial-hepatic venous blood glucose concentration difference 
and the hepatic blood flow, which was determined at 10-20-min intervals. Note that the net SGB is the result of two simultaneously ongoing processes: SGU and HGP. The het SGB (measured by the hepatic venous catheter technique), therefore, reflects neither SGU nor HGP. Fortunately, however, HGP can be measured independently using tritiated glucose. Since both the net SGB and HGP can be independently measured, SGU can be calculated from the relationship, net SGB = HGP - SGU. The SGU also can be calculated as the product of the splanchnic extraction ratio (SER) and the delivery of glucose to the splanchnic bed as follows: $S G U=(S E R) \times($ splanchnic blood flow) $\times$ (arterial blood glucose concentration). In the above equation SER can be calculated from the arterial-hepatic venous difference in $\left[{ }^{3} \mathrm{H}\right] g l u c o s e$ counts divided by the arterial $\left[{ }^{3} \mathrm{H}\right] g l u c o s e$ counts.

Leg glucose uptake was calculated as the product of the arterialfemoral venous blood glucose concentration difference and the leg blood flow, and expressed as milligrams per killigram leg weight per minute.

All data are presented as the mean \pm SEM. All statistical comparisons between different groups were performed by unpaired $t$ test analysis. Changes from base line within any given group were evaluated by the paired $t$ test. Coefficients of correlation were determined by standard procedures.

\section{Results}

\section{Insulin clamp studies}

Plasma glucose and insulin concentrations. The fasting plasma glucose concentration in the diabetic subjects, $158 \pm 5 \mathrm{mg} / \mathrm{dl}$, was significantly greater than in the controls, $99 \pm 3 \mathrm{mg} / \mathrm{dl}(P$ $<0.001)$. The time required for the plasma glucose concentration to decline from hyperglycemic $(158 \mathrm{mg} / \mathrm{dl})$ to euglycemic $(92 \mathrm{mg} / \mathrm{dl})$ levels was $42 \pm 4 \mathrm{~min}$. This represented a rate of fall of $1.63 \pm 0.10 \mathrm{mg} / \mathrm{dl}$ per min. The fasting plasma insulin concentration in the diabetics, $22 \pm 2 \mu \mathrm{U} / \mathrm{ml}$, was significantly greater than in the controls, $13 \pm 1(P<0.01)$. The steady state plasma glucose concentrations in the two groups during the insulin clamp were $90 \pm 1$ and $98 \pm 3 \mathrm{mg} / \mathrm{dl}$, respectively, with coefficients of variation of $4.5 \pm 0.5$ and $3.7 \pm 0.4 \%$, respectively. The mean steady state plasma insulin concentrations during the insulin clamp were $108 \pm 8$ and $97 \pm 5 \mu \mathrm{U} / \mathrm{ml}$ in the diabetics and controls, respectively. The coefficients of variations were $13 \pm 1$ and $8 \pm 1 \%$ in the two groups.

Total body glucose metabolism. The amount of glucose metabolized by the entire body in the diabetic patients during the insulin clamp was $4.37 \pm 0.45 \mathrm{mg} / \mathrm{kg}$ per min which was $38 \%$ lower than in the controls, $7.04 \pm 0.63 \mathrm{mg} / \mathrm{kg}$ per $\min (P$ $<0.01)$. The rate of disappearance calculated from the tritiated glucose turnover data in the diabetic $(4.61 \pm 0.28 \mathrm{mg} / \mathrm{kg}$ per $\mathrm{min})$ and control $(6.63 \pm 0.62 \mathrm{mg} / \mathrm{kg}$ per min) groups was closely correlated $(r=0.933, P<0.001$ and $r=0.903, P$ $<0.001$, respectively) with the measure of glucose utilization obtained by adding the glucose infusion rate to the rate of residual HGP.

The time course of increase in insulin-stimulated glucose uptake is shown in Fig. 2. During all intervals the amount of glucose metabolized by the diabetic patients was significantly lower than that metabolized by controls. The amount of glucose taken up during the insulin clamp in the NIDD group was strongly correlated $(r=0.80, P<0.01)$ with the rate of fall of plasma glucose concentration during the period preceeding euglycemia. Total body glucose metabolism was inversely correlated $(r=0.77, P<0.02)$ with the fasting plasma glucose level.

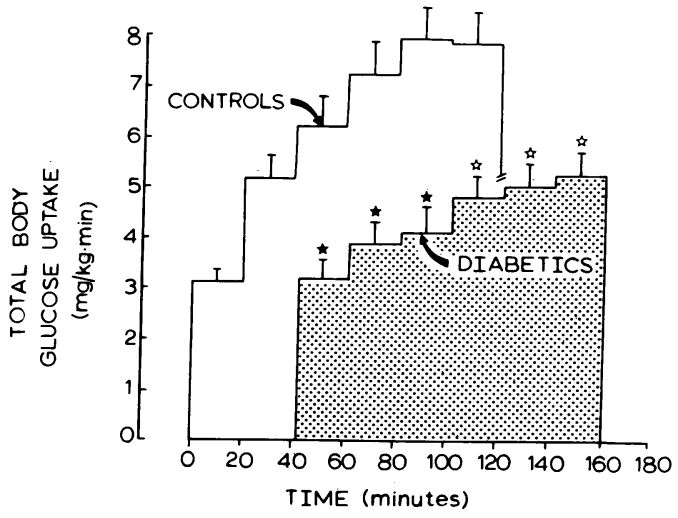

Figure 2. Time course of glucose uptake in control and diabetic subjects during the insulin clamp study. In the diabetics no glucose was infused during the first $\mathbf{4 2} \mathrm{min}$ in order to allow the plasma glucose concentration to decline from hyperglycemic to euglycemic levels. $\star, P<0.05 ; \star, P<0.01$.

Leg blood flow and glucose uptake. In the basal state leg blood flow averaged $0.41 \pm 0.06$ and $0.38 \pm 0.04 \mathrm{liter} / \mathrm{min}$ in the diabetic and the control groups, respectively. This was unchanged during the insulin clamp, $0.43 \pm 0.04$ and $0.43 \pm 0.06$ liter/min. The total amount of glucose taken up by the leg tissues in the basal state was significantly greater in the diabetic subjects, $1.7 \pm 0.2 \mathrm{mg} / \mathrm{kg}$ leg wt per min, than in controls, $1.1 \pm 0.1 \mathrm{mg} / \mathrm{kg}$ leg wt per min $(P<0.02$; Figure 3$)$. In the diabetic group the ability of insulin to stimulate leg glucose uptake was markedly blunted and delayed (Fig. 3). Even during the last hour of insulin clamp leg glucose uptake, $6.0 \pm 0.2 \mathrm{mg} /$ $\mathrm{kg}$ per min, was reduced by $45 \%$ as compared with that in controls $(11.0 \pm 0.1 \mathrm{mg} / \mathrm{kg}$ per min, $P<0.01)$. In both diabetic and control subjects, leg glucose uptake during the last hour was strongly correlated with the total amount of glucose taken up by the entire body during the insulin clamp $(r=0.70 ; P$ $<0.01$; Fig. 4).

Splanchnic blood flow and glucose metabolism. In the postabsorptive state splanchnic blood flow averaged 1.15 \pm 0.09 and $1.20 \pm 0.05 \mathrm{liter} / \mathrm{min}$ in the diabetic and control groups, respectively. This did not change significantly during the insulin clamp, $1.15 \pm 0.8$ and $1.26 \pm 0.06 \mathrm{liter} / \mathrm{min}$. Under basal conditions there was a net release of glucose by the splanchnic

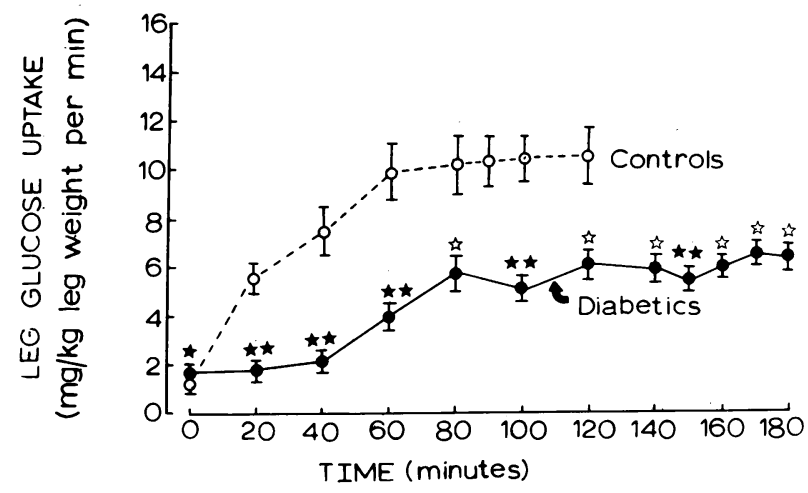

Figure 3. Time course of insulin-stimulated leg glucose uptake in diabetic and control subjects. $\star, P<0.05 ; \star, P<0.01 ; \star \star, P$ $<0.001$. 


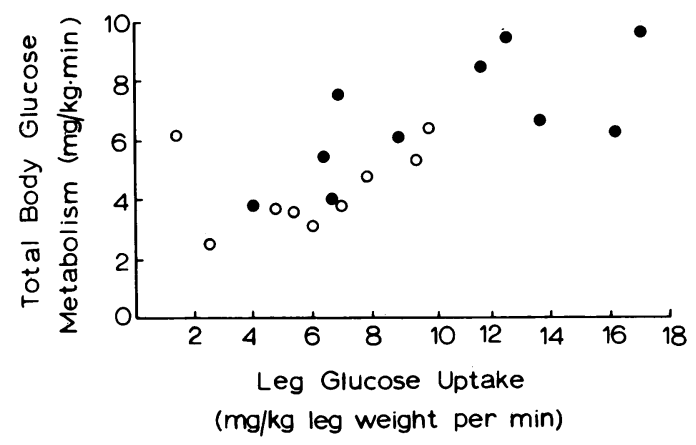

Figure 4. Correlation between total body glucose metabolism and leg glucose uptake in control $(\bullet)$ and diabetic (0) subjects. A highly significant positive correlation $(r=0.70, P<0.001)$ between these two variables was observed.

tissues (measured by the hepatic vein catheter technique), which averaged $1.64 \pm 0.12 \mathrm{mg} / \mathrm{kg}$ per $\min$ in the diabetic subjects and 1.76 \pm 0.16 in the controls (not significant; Fig. 5). After the infusion of insulin there was a prompt inhibition of glucose release by the splanchnic area. By $20 \mathrm{~min}$ SGB was still negative in the diabetic patients, $0.14 \pm 0.12 \mathrm{mg} / \mathrm{kg}$ per min, but slightly positive in the controls, $0.05 \pm 0.15 \mathrm{mg} / \mathrm{kg}$ per min (not significant). By 80 min net SGB was positive in both diabetic $(0.18 \pm 0.10 \mathrm{mg} / \mathrm{kg}$ per $\mathrm{min})$ and control subjects $(0.41 \pm 0.09 \mathrm{mg} / \mathrm{kg}$ per min, $P=0.10)$ and remained positive in both groups thereafter (Fig. 5). The mean net SGB during the last $100 \mathrm{~min}$ of the insulin clamp was slightly lower in the diabetic group than in controls $(0.05 \pm 0.09$ vs. $0.31 \pm 0.10 \mathrm{mg} /$ kg per min, $P=0.07$; Fig. 5).

In the basal state HGP (as evaluated by infusion of tritiated glucose) was slightly less in the control $(2.17 \pm 0.12 \mathrm{mg} / \mathrm{kg}$ per $\mathrm{min})$ than in the diabetic $(2.50 \pm 0.08 \mathrm{mg} / \mathrm{kg}$ per $\mathrm{min})$ group $(P<0.05$; Fig. 6). In both groups insulin caused a prompt suppression of hepatic glucose output (Fig. 6). During the last $100 \mathrm{~min}$ of the insulin clamp HGP was slightly greater in the

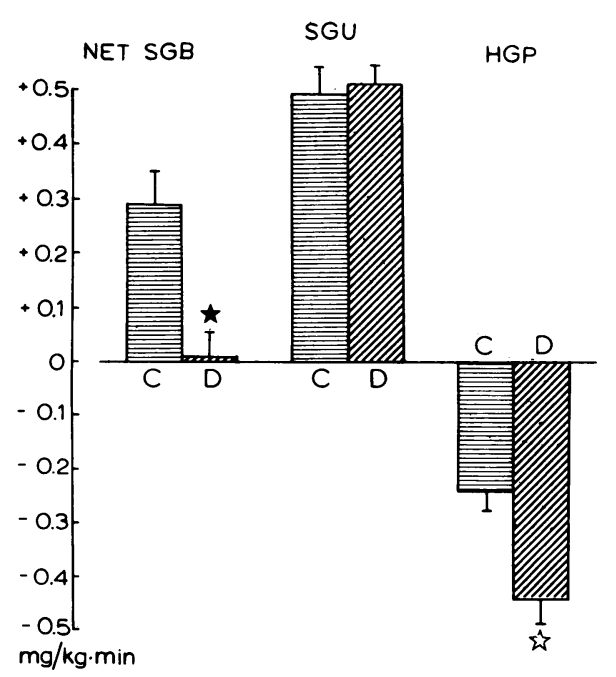

Figure 5. Summary of the net SGB, SGU, and suppression of HGP during the last $100 \mathrm{~min}$ of the euglycemic insulin clamp in control $(C)$ and diabetic $(D)$ subjects. $\star, P=0.07$ for net SGB; $\star P<0.05$ for HGP.

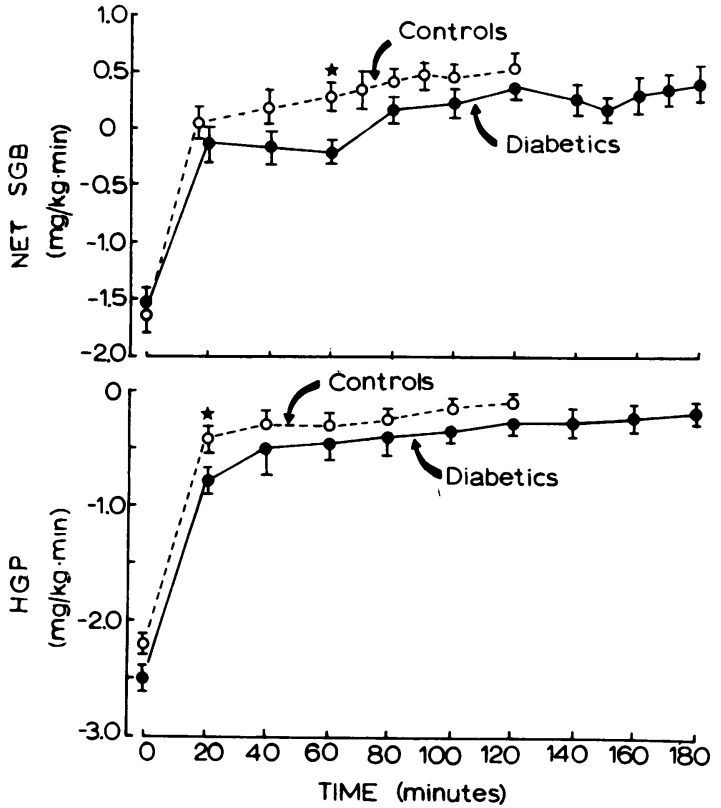

Figure 6. Time course of change in HGP $\left(\left[{ }^{3} \mathrm{H}\right] 3\right.$-glucose; top $)$ and net SGB (hepatic venous catheterization; bottom) in diabetic and control subjects. $\star, P<0.05$.

diabetic than in the control group $(0.35 \pm 0.10$ vs. $0.16 \pm 0.05$ $\mathrm{mg} / \mathrm{kg}$ per min, $P<0.01$; Fig. 5).

SGU during the postabsorptive state was estimated in two ways. When calculated as the difference between the net SGB (hepatic vein catheter) and HGP (tritiated glucose), a small difference between NIDD $(0.86 \pm 0.12 \mathrm{mg} / \mathrm{kg}$ per $\mathrm{min})$ and controls $(0.44 \pm 0.11 \mathrm{mg} / \mathrm{kg}$ per $\mathrm{min})$ was observed $(P<0.05)$. SGU during the basal state was also calculated as the product of the splanchnic extraction ratio (arterial minus hepatic venous $\left[{ }^{3} \mathrm{H}\right]$ glucose counts/arterial $\left[{ }^{3} \mathrm{H}\right]$ glucose counts) and the glucose delivered to the splanchnic area (splanchnic plasma flow $X$ arterial plasma glucose concentration). Hepatic vein tritiated glucose counts were available in all diabetic subjects but only for 5 of the 10 controls. When calculated in this manner the SGU in diabetic subjects $(0.48 \pm 0.07 \mathrm{mg} / \mathrm{kg}$ per min) was similar to that in controls $(0.40 \pm 0.08 \mathrm{mg} / \mathrm{kg}$ per min). In neither group did insulin stimulate SGU above basal values. During the insulin clamp the splanchnic extraction ratio in diabetics $(3.3 \pm 0.5 \%)$ and controls $(4.1 \pm 0.5 \%)$ was similar.

Counterregulatory hormones. No increase in plasma cortisol, growth hormone, or epinephrine was observed in any diabetic individual during the period when the plasma glucose concentration was dropped from hyperglycemic to euglycemic levels (Table I). A small and statistically insignificant rise in plasma cortisol (in four of nine patients) and growth hormone (in six of nine) was observed $60 \mathrm{~min}$ before the end of the euglycemic insulin clamp (Table I). In only two diabetic subjects was a rise in plasma epinephrine noted during the initial 60-min period of euglycemic hyperinsulinemia. During the last hour of euglycemic hyperinsulinemia, plasma epinephrine rose in all of the diabetic subjects $(P<0.01$; Table I). A small increase in plasma norepinephrine was observed during the period of falling plasma glucose concentration $(P<0.05)$. There was no further increase in plasma norepinephrine during the 2-h period of euglycemic hyperinsulinemia. 
Table I. Counterregulatory Hormone Levels during the Insulin Clamp Study in NIDD Subjects

\begin{tabular}{|c|c|c|c|c|c|c|c|}
\hline & \multirow[b]{2}{*}{ Basal } & \multicolumn{2}{|c|}{ Insulin } & \multicolumn{4}{|c|}{ Insulin and glucose } \\
\hline & & $30 \mathrm{~min}$ & $42 \min ^{*} / 0$ & $30 \mathrm{~min}$ & $60 \min$ & $90 \min$ & $120 \mathrm{~min}$ \\
\hline Cortisol $(\mu g / d l)$ & $16 \pm 2$ & - & - & $14 \pm 1$ & $22 \pm 2$ & $17 \pm 2$ & $17 \pm 1$ \\
\hline Growth hormone $(\mathrm{ng} / \mathrm{ml})$ & $4 \pm 1$ & - & - & $4 \pm 1$ & $10 \pm 2$ & $9 \pm 2$ & $8 \pm 2$ \\
\hline Glucagon $(p g / m l)$ & $74 \pm 13$ & - & - & $64 \pm 13$ & $60 \pm 13$ & $52 \pm 13$ & $54 \pm 12$ \\
\hline Epinephrine $(p g / m l)$ & $46 \pm 8$ & $47 \pm 8$ & $58 \pm 9$ & $92 \pm 43$ & $81 \pm 31$ & $137 \pm 29$ & $155 \pm 42$ \\
\hline Norepinephrine $(\mathrm{pg} / \mathrm{ml})$ & $240 \pm 25$ & $304 \pm 31$ & $323 \pm 44$ & $305 \pm 19$ & $278 \pm 33$ & $298 \pm 37$ & $328 \pm 45$ \\
\hline
\end{tabular}

* Mean time after insulin was started that it took for the plasma glucose concentration to decline from hyperglycemic levels to $100 \mathrm{mg} / \mathrm{dl}$.

\section{Discussion}

After the ingestion of a $1 \mathrm{~g} / \mathrm{kg}$ glucose load, our diabetic subjects demonstrated marked glucose intolerance despite plasma insulin levels that were significantly greater than in age-matched controls (Fig. 1), suggesting the presence of resistance to the action of insulin. This was confirmed during the euglycemic insulin clamp study; during all intervals insulinmediated glucose uptake by the entire body was diminished by $30-40 \%$ as compared with that in control subjects (Fig. 2).

In an attempt to define the site and mechanisms of the insulin resistance, the clamp studies were performed in combination with hepatic and femoral venous catheterization and infusion of tritiated glucose. The results of the leg catheterization studies provide direct evidence that peripheral tissues represent the primary site of the insulin resistance in NIDD individuals. In the diabetic subjects the ability of insulin to stimulate leg glucose uptake was markedly blunted and delayed, whereas in the control group insulin caused a prompt and marked increase in leg glucose uptake (Fig. 3). Even after $180 \mathrm{~min}$ of hyperinsulinemia, leg glucose uptake was reduced by $45 \%$ as compared with that in controls. In both diabetic and control subjects the amount of glucose taken up by the leg closely parallelled the amount of glucose taken up by the entire body. The importance of peripheral tissues in determining overall glucose disposal is further emphasized by the strong correlation $(r=0.70, P$ $<0.001)$ between leg and total body glucose uptake in both control and diabetic groups. The net splanchnic glucose balance (hepatic venous catheter data) in the diabetic patients during the insulin stimulation was slightly less than in controls, $0.05 \pm 0.09$ vs. $0.31 \pm 0.10 \mathrm{mg} / \mathrm{kg}$ per min (Figs. 5 and 6 ). This difference $\left(0.26 \mathrm{mg} / \mathrm{kg}\right.$ per $\left.\mathrm{min}^{-1}\right)$ represents only a small fraction $(10 \%)$ of the reduction $(2.67 \mathrm{mg} / \mathrm{kg}$ per min) in total body glucose uptake in NIDD as compared with controls. Thus, the femoral and hepatic venous catheter data demonstrate that peripheral tissues represent the quantitatively most important site of insulin resistance in NIDD.

The quantitative contribution of peripheral tissues to total body glucose disposal can be estimated by extrapolating from our leg glucose uptake measurements. Björntorp et al. $(24,25)$ determined that $<1 \%$ of an intravenous or oral glucose load is disposed of by adipose tissue. If it is assumed that most leg glucose uptake occurs in muscle tissue and that muscle tissue represents $64 \%$ of total leg weight (26), it can be calculated that glucose uptake by leg muscle was $14.8 \mathrm{mg} / \mathrm{kg}$ per min (based on total leg glucose uptake of $9.5 \mathrm{mg} / \mathrm{kg}$ per min) during the last $100 \mathrm{~min}$ of the euglycemic insulin clamp in the control group. For a $70-\mathrm{kg}$ man, the total muscle mass is $\sim 30 \mathrm{~kg}$ (27). Since the mean weight of our control group was $74 \mathrm{~kg}$, total body muscle mass would be $32 \mathrm{~kg}$. If all muscle tissue in the body responds to insulin in a way similar to how leg muscle responds, total muscle glucose uptake can be calculated to be $470 \mathrm{mg} / \mathrm{min}$ or $47 \mathrm{~g}$ over the last $100 \mathrm{~min}$ of the clamp study. During the same period the total body glucose uptake during the insulin clamp was $7.0 \mathrm{mg} / \mathrm{kg}$ per min or 52 g. It can thus be estimated that muscle tissues accounted for $90 \%$ ( 47 of $52 \mathrm{~g}$ ) of total body glucose disposal. SGU during the last $100 \mathrm{~min}$ of the insulin clamp amounted to $\sim 2 \mathrm{~g}$ (body weight, $74 \mathrm{~kg}$; net $\mathrm{SGB}=0.31 \mathrm{mg} / \mathrm{kg}$ per min) or only $4 \%$ of total body glucose uptake $(52 \mathrm{~g})$.

In the diabetic subjects total body glucose uptake during the last $100 \mathrm{~min}$ of the insulin clamp averaged $4.4 \mathrm{mg} / \mathrm{kg}$ per min or $31 \mathrm{~g}$. Under the assumptions outlined above, splanchnic and muscle glucose uptake amounted to 0.6 and $27 \mathrm{~g}$ or 1 and $87 \%$ of total body glucose uptake, respectively. Thus, in the diabetic group as well as in the controls peripheral tissues are the most important determinant of overall glucose disposal.

Since splanchnic, peripheral, and total body glucose uptake were independently measured, their internal consistency indicates that these individual determinations must be reasonably accurate. Moreover, they leave an amount of glucose unaccounted for that is of the order of magnitude of the expected glucose uptake by noninsulin-dependent tissues, primarily brain. Estimates from the literature $(28-30)$ indicate that cerebral tissues use glucose at the rate of $0.8-1.0 \mathrm{mg} / \mathrm{kg}$, which amounts to $\sim 6-7 \mathrm{~g}$ during the last $100 \mathrm{~min}$ of the insulin clamp in both the control and diabetic subjects. This is in reasonably good agreement with the amount of glucose (3-4 g) unaccounted for by muscle and splanchnic tissues.

The simultaneous measurements of SGB and HGP, using the tritiated glucose kinetic analysis, allowed us to estimate SGU. As can be seen in Fig. 5, SGU was nearly identical in control and diabetic subjects. It should also be emphasized that in the control group insulin failed to stimulate SGU above the level observed in the postabsorptive state. This observation is consistent with previously published results obtained in healthy young subjects $(31,32)$. In addition, glucose uptake by the splanchnic (hepatic and extrahepatic splanchnic) tissues in NIDD subjects appears to be insulin independent, just as it is in control individuals. These observations suggest that under conditions of euglycemic hyperinsulinemia peripheral tissues represent the primary site of insulin resistance in type II diabetes mellitus.

In diabetic subjects there was a slight decrease in net SGB as compared with in controls. This was due to a mild impairment in the ability of insulin to suppress HGP (Figs. 5 and 6). 
In previous studies we could not demonstrate any significant difference in the ability of insulin to inhibit HGP between controls and NIDD with a comparable degree of fasting hyperglycemia $(8,9)$, but other investigators have shown a modest impairment in the suppressive action of insulin on HGP in NIDD patients with more severe fasting hyperglycemia, $>200-220 \mathrm{mg} / \mathrm{dl}(10,11)$. These variable results with regard to the suppression of HGP by insulin in NIDD may be due to the fact that none of these studies, including the present one, were ideally designed to examine hepatic sensitivity to insulin. Suppression of HGP is $>90 \%$ when the plasma insulin concentration is raised by $>100 \mu \mathrm{U} / \mathrm{ml}$ and $\sim 75-80 \%$ complete with increments in plasma insulin of only $50 \mu \mathrm{U} / \mathrm{ml}$ (32). Therefore, if one specifically wants to examine hepatic sensitivity to insulin, levels between 10 and $50 \mu \mathrm{U} / \mathrm{ml}$ should be employed. It is quite possible that at these lower plasma insulin concentrations, i.e., $10-50 \mu \mathrm{U} / \mathrm{ml}$, a defect in the ability of insulin to suppress HGP may be observed.

It could be argued that the decline in plasma glucose concentration from hyperglycemic to euglycemic levels before the insulin clamp was started elicited a counterregulatory hormonal response and that this was responsible for the insulin resistance observed in the NIDD subjects. This seems unlikely for several reasons. First, during the initial $60 \mathrm{~min}$ of the euglycemic insulin clamp there was no significant rise in arterial concentrations of insulin counterregulatory hormones (Table I). Although plasma norepinephrine levels increased during this period, this hormone is not known to exert any deleterious effects on glucose utilization. Second, during the last $60 \mathrm{~min}$ of the euglycemic insulin clamp only plasma epinephrine rose significantly. However, the absolute rise was small and the rate of glucose utilization continued to rise, rather than fall, during this period. Furthermore, leg glucose uptake (Fig. 3) was markedly reduced during the first $102 \mathrm{~min}$ after insulin infusion, whereas plasma epinephrine levels did not increase significantly from basal. This impairment in leg glucose uptake during the 0-102 min period was of similar magnitude to that observed during the last hour of the study. Therefore, we do not believe that the small increase in plasma epinephrine, observed only during the last hour, can account for the severe peripheral resistance to insulin. Some comment about the age difference ( $9 \mathrm{yr}$ ) between the diabetic and control groups is indicated since we, as well as others, have shown that tissue sensitivity to insulin declines with advancing age $(33,34)$. From Fig. 4 of reference 34 , it can be calculated that as an individual ages from 43 to 52 one can expect total body glucose uptake to decline by $<0.3-0.4 \mathrm{mg} / \mathrm{kg} \cdot \mathrm{min}$. This decrease is quite small as compared with the magnitude of the impairment $(\Delta=2.67 \mathrm{mg} / \mathrm{kg} \cdot \mathrm{min})$ in insulin sensitivity observed in our diabetic subjects. Furthermore, remember that the insulin clamp study in the diabetics lasted 42 min longer in the control group. Since there is a time-dependent increase in glucose disposal after insulin administration (35), comparison of glucose uptake during the last hour of the insulin clamp study would tend to underestimate the true severity of the insulin resistance in the diabetic group.

In summary, the present results demonstrate that the ability of insulin to stimulate glucose uptake in NIDD is markedly impaired. Quantitatively, the most important site of this insulin resistance resides in peripheral tissues, probably muscle, and the splanchnic tissues play only a minor role in the impairment in insulin-mediated glucose utilization.

\section{Acknowledgments}

The authors thank Dr. Rosa Hendler for performing the insulin determinations. Anita Furö provided technical assistance in preparation of the manuscript.

This work was supported in part by National Institutes of Health grant AM 24092, Clinical Research Center grant RR 125, The Swedish Medical Research Council (43108), the Swedish Diabetes Association, and the Karolinska Institute.

\section{References}

1. DeFronzo, R. A., E. Ferrannini, and V. Koivisto. 1983. New concepts in the pathogenesis and treatment of non-insulin-dependent diabetes mellitus. Am. J. Med. 74(Suppl. 1):52-81.

2. Himsworth, H. P., and R. B. Carr. 1942. Insulin-sensitive and insulin-insensitive types of diabetes mellitus. Clin. Sci. 4:120-152.

3. Alford, F. P., F. I. Martin, and M. J. Pierson. 1971. The significance of interpretation of mildly abnormal oral glucose tolerance. Diabetologia. 7:173-180.

4. Efendic, S., A. Wajngot, E. Cerasi, and R. Luft. 1980. Insulin release, insulin sensitivity and glucose intolerance. Proc. Natl. Acad. Sci. USA. 77:7425-7429.

5. Ginsberg, H., G. Kimmerling, J. M. Olefsky, and G. M. Reaven. 1975. Demonstration of insulin resistance in untreated adult-onset diabetic subjects with fasting hyperglycemia. J. Clin. Invest. 55:454461.

6. Olefsky, J., J. W. Farquhar, and G. Reaven. 1973. Relationship between fasting plasma insulin level and resistance to insulin-mediated glucose uptake in normal and diabetic subjects. Diabetes. 22:507-513.

7. Bowen, H. F., and J. A. Moorehouse. 1973. Glucose turnover and disposal in maturity-onset diabetes. J. Clin. Invest. 52:3033-3045.

8. DeFronzo, R. A., D. Deibert, R. Hendler, P. Felig, and V. Soman. 1979. Insulin sensitivity and insulin binding to monocytes in maturity-onset diabetes. J. Clin. Invest. 63:939-946.

9. DeFronzo, R. A., D. Simonson, and E. Ferrannini. 1982. Hepatic and peripheral insulin resistance: a common feature in non-insulin dependent and insulin dependent diabetes. Diabetologia. 23:313-319.

10. Kolterman, O. G., R. S. Gray, J. Griffin, P. Burstein, J. Insel, J. A. Scarlett, and J. M. Olefsky. 1981. Receptor and post-receptor defects contribute to the insulin resistance in non-insulin-dependent diabetes mellitus. J. Clin. Invest. 68:957-969.

11. Scarlett, J. A., R. S. Gray, J. Griffin, J. M. Olefsky, and O. G. Kolterman. 1982. Insulin treatment reverses the insulin resistance of Type II diabetes mellitus. Diabetes Care. 5:353-363.

12. Rizza, R. A., L. J. Mandarino, and J. E. Gerich. 1981. Mechanism and significance of insulin resistance in non-insulin-dependent diabetes mellitus. Diabetes. 30:990-995.

13. National Diabetes Data Group. 1979. Classification and diagnosis of diabetes mellitus and other categories of glucose intolerance. Diabetes. 28:1039-1057.

14. Jorfeldt, L., and J. Wahren. 1971. Leg blood flow during exercise in man. Clin. Sci. 41:459-473.

15. Felig, P., and J. Wahren. 1971. Influence of endogenous insulin secretion on splanchnic glucose and amino acid metabolism. J. Clin. Invest. 50:1702-1709.

16. DeFronzo, R. A., J. E. Tobin, and R. Andres. 1979. The glucose clamp technique. A method for the quantification of beta cell sensitivity to glucose and of tissue sensitivity to insulin. Am. J. Physiol. 237:E214-E223.

17. Blackard, W. G., and N. C. Nelson. 1970. Portal and peripheral vein immunoreactive insulin concentrations before and after glucose infusion. Diabetes. 19:302-306.

18. Wahren, J., P. Felig, and L. Hagenfeldt. 1976. Effect of protein ingestion on splanchnic and leg glucose metabolism in normal man and in patients with diabetes mellitus. J. Clin. Invest. 57:987-999.

19. Rosselin, G. R., S. Assan, R. Yalow, and S. A. Berson. 1966. Separation of antibody bound and unbound peptide hormones with 
iodine- ${ }^{125}$ by talcum powder and precipitated silica. Nature (Lond.). 194:495-496.

20. Wise, J. K., R. Hendler, and P. Felig. 1973. Influence of glucocorticoids on glucagon secretion and plasma amino acid concentrations in man. J. Clin. Invest. 52:2774-2782.

21. Cryer, P. E. 1976. Isotope-derivative measurement of plasma norepinephrine and epinephrine in man. Diabetes. 25:1071-1085.

22. DeFronzo, R. A., and N. J. Christensen. 1980. Stimulation of counterregulatory hormonal responses in diabetic man by a fall in glucose concentration. Diabetes. 28:125-131.

23. Pilo, A., E. Ferrannini, O. Björkman, J. Wahren, G. A. Reichard, P. Felig, and R. A. DeFronzo. 1981. Analysis of glucose production and disappearance rates following an oral glucose load in normal subjects: a double tracer approach. In Carbohydrate Metabolism. Quantitative Physiology and Mathematical Modeling. C. Cobelli and R. N. Bergman, editors. John Wiley \& Sons, New York. 221-238.

24. Björntorp, P., M. Krotkiewski, B. Larson, and A. SoimloSzuck. 1970. Effects of feeding states on lipid radioactivity in liver, muscle and adipose tissue after injection of labeled glucose in the rat. Acta Physiol. Scand. 80:28-38.

25. Björntorp, P., P. Berchtold, and B. Larson. 1971. The glucose uptake of human adipose tissue in obesity. Eur. J. Clin. Invest. 1:480483.

26. Stolwijk, J. A. J., and J. D. Hardy. 1966. Temperature regulation in man. A theoretical study. Art. Ges. Physiol. 291:152153.
27. Björntorp, P., and L. Sjöstrom. 1978. Carbohydrate metabolism in man. Speculations and some quantitative considerations. Metab. Clin. Exp. 27(Suppl. 2):1853-1863.

28. Reinmuth, O. M., P. Scheinberg, and B. Bourne. 1965. Total cerebral blood flow and metabolism. Arch. Neurol. 12:49-66.

29. Owen, O. E., A. P. Morgan, H. G. Kemp, J. M. Sullivan, M. G. Herrera, and G. F. Cahill. 1967. Brain metabolism during fasting. J. Clin. Invest. 46:1589-1595.

30. Huang, S. C., M. E. Phelps, E. J. Hoffman, K. Sideris, C. H. Selin, and D. E. Kuhl. 1980. Noninvasive determination of local cerebral metabolic rate of glucose in man. Am. J. Physiol. 238:E69E82.

31. DeFronzo, R. A., A. Alvestrand, D. Smith, R. Hendler, E. Hendler, and J. Wahren. 1981. Insulin resistance in uremia. J. Clin. Invest. 67:563-568.

32. DeFronzo, R. A., E. Ferrannini, R. Hendler, P. Felig, and J. Wahren. 1983. Regulation of splanchnic and peripheral glucose uptake by insulin and hyperglycemia in man. Diabetes. 32:35-45.

33. DeFronzo, R. A. 1979. Glucose intolerance and aging. Evidence for tissue insensitivity to insulin. Diabetes. 28:1095-1101.

34. DeFronzo, R. A. 1981. Glucose intolerance and aging. Diabetes Care. 4:493-501.

35. Doberne, L., M. Greenfield, B. Schultz, and G. Reaven. 1981. Enhanced glucose utilization during prolonged clamp studies. Diabetes. 30:829-835. 